MS

Editions

BOLETIN LATINOAMERICANO Y DEL CARIBE DE PLANTAS MEDICINALES Y AROMÁTICAS 19 (6): 614 - $627(2020)$

(C) / ISSN 07177917 / www.blacpma.ms-editions.cl

\title{
Articulo Original / Original Article Antimicrobial activity of essential oil from Psidium cattleianum Afzel. ex Sabine leaves
}

[Actividad antimicrobiana del aceite esencial de hojas de Psidium cattleianum Afzel. ex Sabine]

\author{
Thais Lorana Savoldi ${ }^{1}$, Jasmina Glamoćlija ${ }^{2}$, Marina Soković ${ }^{2}$ José Eduardo Gonçalves $^{3}$, Suelen Pereira Ruiz ${ }^{1}$, \\ Giani Andrea Linde ${ }^{1}$, Zilda Cristiani Gazim ${ }^{1}$ \& Nelson Barros Colauto ${ }^{1}$ \\ ${ }^{1}$ Graduate Program in Biotechnology Applied to Agriculture, Paranaense University Umuarama, Paraná, Brazil \\ ${ }^{2}$ Department of Plant Physiology, Institute for Biological Research Siniša Stanković - National Institute of Republic of Serbia, \\ University of Belgrade, 11000 Belgrade, Serbia \\ ${ }^{3}$ Master Program in Clean Technology, Master Program in Science, Technology and Food Safety, and Cesumar Institute of Science, \\ Technology and Innovation, Cesumar University Center, Maringá, Paraná, Brazil \\ Contactos | Contacts: Suelen Pereira RUIZ - E-mail address: suelenruiz@prof.unipar.br
}

\begin{abstract}
The search for natural sources to control microorganisms is of interest in food production. This study evaluated the chemical composition and antimicrobial activity of the essential oil from Psidium cattleianum leaves. The essential oil was extracted by hydrodistillation, and identified by GC-MS. The predominant class of compounds was sesquiterpenes (47.6\%) and the major compounds were trans- $\beta$-caryophyllene (14.7\%), 1,8-cineole (11.7\%) and $\gamma$-muurolene $(5.6 \%)$. The antimicrobial activity was carried out by microdillution technique against eight fungi and eight bacteria. The minimum inhibitory concentration ranged from 0.17 to $11.25 \mathrm{mg} \mathrm{mL}-1$ for fungi, and from 1.40 to $16.87 \mathrm{mg} \mathrm{mL}-1$ for bacteria. The highest activities were against fungi Aspergillus fumigatus (ATCC 1022), Aspergillus ochraceus (ATCC 12066), Aspergillus versicolor (ATCC 11730), and Trichoderma viride (IAM 5061), and bacteria Pseudomonas aeruginosa (ATCC 27853), Bacillus cereus (clinical isolate), and Staphylococcus aureus (ATCC 6538) with potential to prevent foodborne diseases.
\end{abstract}

Keywords: 1,8-cineole; Psidium cattleianum essential oil; Bactericide; Fungicide; trans- $\beta$-caryophyllene; $\gamma$-muurolene.

Resumen: La búsqueda de fuentes naturales para controlar los microorganismos es de interés en la producción de alimentos. Este estudio evaluó la composición química y la actividad antimicrobiana del aceite esencial de las hojas de Psidium cattleianum. El aceite esencial se extrajo por hidrodestilación y se identificó por GC-MS. La clase predominante de compuestos fueron los sesquiterpenos (47,6\%) y los principales fueron trans- $\beta$-cariofileno (14,7\%), 1,8-cineol (11,7\%) y $\gamma$-muuroleno $(5,6 \%)$. Actividad antimicrobiana se realizó mediante la técnica de microdilución contra ocho hongos y ocho bacterias. Concentración inhibitoria mínima varió de 0,17 a $11,25 \mathrm{mg} \mathrm{mL}-1$ para hongos y de 1,40 a 16,87 mg mL-1 para bacterias. Principales actividades fueron contra hongos Aspergillus fumigatus (ATCC 1022), Aspergillus ochraceus (ATCC 12066), Aspergillus versicolor (ATCC 11730) y Trichoderma viride (IAM 5061), y bacterias Pseudomonas aeruginosa (ATCC 27853), Bacillus cereus (clinical isolate) y Staphylococcus aureus (ATCC 6538) con potencial para prevenir enfermedades transmitidas por alimentos.

Palabras clave: 1,8-cineol; Psidium cattleianum aceite essencial; Bactericida; Fungicida; trans- $\beta$-cariofileno; $\gamma$-muuroleno.

Recibido | Received: February 15, 2020

Aceptado | Accepted: March 20, 2020

Aceptado en versión corregida | Accepted in revised form: March 25, 2020

Publicado en línea | Published online: July 30, 2020

Este artículo puede ser citado como / This article must be cited as: TL Savoldi, J Glamoćlija, M Soković, JE Gonçalves, SP Ruiz, GA Linde, ZC Gazim, NB Colauto. 2020. Antimicrobial activity of essential oil from Psidium cattleianum Afzel. ex Sabine leaves. Bol Latinoam Caribe Plant Med Aromat 19 (6): 614 - 627.

https://doi.org/10.37360/blacpma.20.19.6.44 


\section{INTRODUCTION}

Microorganisms are considered one of the principal responsible sources of food deterioration which produces mycotoxins that can be fatal if eaten. The losses in food processing, due to contamination by microorganisms, are hard to be estimated (Rawat, 2015; Pandey et al., 2016). Besides these losses, foodborne diseases affect approximately $10 \%$ of the world population yearly, and the most frequent etiologic agent is bacteria (WHO, 2015). In order to control microorganisms, antimicrobial substances are used in human and animal health (FAO, 2017). The massive use of these compounds resulted in the development of microorganisms that are resistant to several antibiotics, and become a public health problem (Andreotti \& Nicodemo, 2004). It has been estimated that infections resistant to medications will risk around 10 million human lives a year if no action is taken by 2050; the generated economic impact will be US\$ 100 trillion dollars in the economic production (O’Neill, 2016). Stefanakis et al. (2013) reported that essential oils could be used as a tool to reduce bacterial dissemination and to control bacterial resistance. Therefore, it has become important to search for natural compounds from plants to control microorganisms (Guimarães et al., 2010).

Brazil has approximately $20 \%$ of the world plant diversity (Modolo \& Foglio, 2019), which represents a great potential to obtain new biomolecules. These molecules can aggregate value to the food, cosmetic, and pharmaceutical industries, mainly due to their antioxidant and antimicrobial properties (Pandey et al., 2016; Salen et al., 2018). It is estimated that out of 300,000 plant species in the world, only $15 \%$ has been evaluated to determine their biological activities, showing that the development of new products from natural sources is still a field of opportunities to be studied (De Lucas et al., 2012).

Psidium cattleianum Afzel. ex Sabine (Myrtaceae) has 21 synonyms (Hassler, 2020) and presents reddish or yellowish fruits. It is popularly known in Brazil as little guava, red araçá and yellow araçá to name just a few. It is natively distributed in Brazil, Oceania, the Caribbean Basin, and North America (McCook-Russell et al., 2012). The species is characterized as a small perennial fruit tree or bush that can vary from 1 to $4 \mathrm{~m}$ in height. The fruits are 2.2 to $5 \mathrm{~cm}$ long, have oval or oblong shape, and present mass smaller than $20 \mathrm{~g}$ with many seeds (Dos Santos Pereira et al., 2018).
The essential oil from $P$. cattleianum (red fruit) leaves was reported to have antifungal activity against several Candida spp. (Castro et al., 2015), but it was inactive against Aspergillus flavus (ATCC 15517) (Soliman et al., 2016). In preliminary tests in our laboratory, $P$. cattleianum essential oil showed antifungal activity against Aspergillus spp. (locally isolated microorganism; data not published). In addition, it has shown antibacterial activity against Staphylococcus aureus (ATCC 12600), Escherichia coli (ATCC 11775), Pseudomonas aeruginosa (ATCC 10145), and Neisseria gonorrhoeae (ATCC 19424) in a qualitative assay with ampicillin as control (Soliman et al., 2016). Dias et al. (2018) reported that the essential oil from Psidium myrtoides Berg (purple araçá) leaves presented antibacterial activity against several Streptococcus spp.

Despite some reports on the antimicrobial activity of the essential oil from $P$. cattleianum leaves, the spectrum of antimicrobial activity against agents that cause deterioration and foodborne diseases has been little explored. Thus, this study aimed to evaluate the chemical composition and antimicrobial activity of the essential oil from $P$. cattleianum (red fruit) dried leaves against a broad spectrum of fungi and bacteria that cause foodborne diseases.

\section{MATERIAL AND METHODS Plant material}

Psidium cattleianum Afzel. ex Sabine (red fruit) leaves were collected in the vegetative phonological phase at the coordinates of latitude $25^{\circ} 56^{\prime} 28^{\prime \prime}$ 'S and longitude $52^{\circ} 10^{\prime} 32^{\prime \prime} \mathrm{W}$, altitude of $921 \mathrm{~m}$, from January to February 2015. A voucher was authenticated, and deposited in the Herbarium of Maringá State University under the number HUEM30716. This species is registered in the National System of Genetic Heritage Management and Associated Traditional Knowledge (SisGen, in Portuguese) under the registration number A344082.

\section{Essential oil extraction}

For the essential oil extraction, the leaves were dried at room temperature, and submitted to hydrodistillation process for $2 \mathrm{~h}$ in a modified Clevenger apparatus (Marques et al., 2008). The essential oil was withdrawn from the apparatus with $n$-hexane, filtered in anhydrous sodium sulfate $\left(\mathrm{Na}_{2} \mathrm{SO}_{4}\right)$, stored in an amber flask and kept at $-20^{\circ} \mathrm{C}$ until complete solvent evaporation (Castro et al., 2015). The essential oil yield was calculated by the 
essential oil mass divided by the plant dried leaf mass, multiplied by 100, and expressed in percentage.

\section{Chemical composition of the essential oil}

The essential oil chemical identification was carried out by a gas chromatographer (Agilent 7890B) coupled to a mass spectrometer (Agilent 5977A MSD) (GC-MS). The capillary column was HP5-MS UI $5 \%(30 \times 250 \mu \mathrm{m} \times 0.25 \mu \mathrm{m} ;$ Agilent Technologies) with initial oven temperature from $60^{\circ} \mathrm{C}$ to $280^{\circ} \mathrm{C}\left(3^{\circ} \mathrm{C} \mathrm{min}-1\right.$ and maintained for $\left.1 \mathrm{~min}\right)$. Helium was utilized as the carrier gas at the linear speed of $1 \mathrm{~mL} \mathrm{~min}{ }^{-1}$ up to $300^{\circ} \mathrm{C}$, and pressure release of 8.23 psi. The injector temperature was $220^{\circ} \mathrm{C}$; the injection volume was $1 \mu \mathrm{L}$; the injection occurred in split mode (20:1) with injector temperature kept at $220^{\circ} \mathrm{C}$. The temperatures of the transfer line, ion source, and quadrupole were 260 , 230 and $150^{\circ} \mathrm{C}$, respectively. The mass spectrometry detection system was utilized in "scan" mode, in the mass/charge range of 40 to $500 \mathrm{~m} / \mathrm{z}$ with 3 -min solvent delay. The compounds were identified by comparing the mass spectra found in NIST 11.0 libraries and by comparing the retention indices (RI) obtained by a homologous series of $n$-alkane standard (C7-C28) (Adams, 2017).

\section{Antifungal activity}

For the antifungal bioassays, eight fungi of the following species were used: Aspergillus fumigatus Fresenius (ATCC 1022), Aspergillus ochraceus Batista et Maia (ATCC 12066), Aspergillus niger van Tieghem (ATCC 6275), Aspergillus versicolor (Vuillemin) Tiraboschi (ATCC 11730), Penicillium funiculosum Thom (ATCC 8725), Penicillium ochrochloron Biourge (ATCC 90288), Penicillium verrucosum var. cyclopium (Westling) Samson, Stolk \& Hadlok (food isolate), and Trichoderma viride Pers. (IAM 5061). The microorganisms were kept in malt extract agar at $4{ }^{\circ} \mathrm{C}$, and subcultivated every 30 days (Booth, 1971). For the evaluation of the antifungal activity of the essential oil, the modified microdilution technique was used (Hänel \& Raether, 1988; Espinel-Ingroff, 2001). The fungal spores were washed from the agar plate surfaces with an aqueous sterile solution containing $8.5 \mathrm{mg} \mathrm{mL}^{-1} \mathrm{NaCl}$ and 1 $\mathrm{mg} \mathrm{mL} \mathrm{mL}^{-1}$ polysorbate- 80 . The spore suspension was adjusted with solution up to $1.0 \times 10^{5}$ spores for 100 $\mu \mathrm{L}$ per well. The inoculum dilutions were cultivated in malt extract agar to verify the absence of contamination and the inoculum validity. The minimum inhibitory concentration (MIC) was determined by serial dilution, utilizing microtiter plates with 96 wells. The essential oil was diluted (0.1-100 $\left.\mathrm{mg} \mathrm{mL}^{-1}\right)$ in aqueous solution containing 50 $\mathrm{mL} \mathrm{L}^{-1}$ dimethyl sulfoxide (DMSO) with $1 \mathrm{mg} \mathrm{mL}^{-1}$ polysorbate-80, and added in malt extract broth cultivation medium (MA) with inoculum. The microplates were incubated in a rotary agitator (160 $\mathrm{rpm}$ ) for $72 \mathrm{~h}$ at $28^{\circ} \mathrm{C}$. The smallest concentrations without visible growth in optical microscope were defined as MIC. The minimum fungicidal concentration (MFC) was determined by serial subcultivation, utilizing $2 \mu \mathrm{L}$ of broth per well into microplates containing $100 \mu \mathrm{L}$ MA for $72 \mathrm{~h}$ at $28^{\circ} \mathrm{C}$. The lowest concentration without visible growth was defined as MFC, indicating $99.5 \%$ of death of the original inoculum. The negative control was an aqueous solution of $50 \mathrm{~mL} \mathrm{~L}^{-1} \mathrm{DMSO}$, and the positive controls were the commercial fungicides bifonazole (Srbolek, Belgrade, Serbia) and ketoconazole (Zorkapharma, Sabac, Serbia) (Gupta et al., 1994), and the food additives sodium sulphite (E221) and potassium metabisulphite (E224) (GarciaFuentes et al., 2015) from 0.001 to $3.5 \mathrm{mg} \mathrm{mL}^{-1}$.

\section{Antibacterial activity}

The antibacterial activity of the essential oil was tested in eight bacterial strains such as Gram-positive Bacillus cereus Frankland and Frankland (clinical isolate), Listeria monocytogenes (Murray et al.) Pirie (NCTC 7973), Micrococcus luteus (Schroeter) Cohn (ATCC 10240), and Staphylococcus aureus subsp. aureus Rosenbach (ATCC 6538), and Gram-negative Enterobacter cloacae (Jordan) Hormaeche and Edwards (clinical isolate), Escherichia coli (Migula) Castellani and Chalmers (ATCC 35218), Pseudomonas aeruginosa (Schroeter) Migula (ATCC 27853), and Salmonella enterica subsp. enterica (ex Kauffmann and Edwards) Le Minor and Popoff serovar Typhimurium (ATCC 13311).

The method of microdilution in broth (CLSI, 2015) using 96-well microplates was utilized for the assays. The bacterial suspensions were standardized with sterile saline solution up to the concentrations of $1.0 \times 10^{5} \mathrm{CFU} \mathrm{mL} \mathrm{m}^{-1}$ (Hänel \& Raether, 1988; Espinel-Ingroff, 2001). The inoculum was prepared daily and stored at $4{ }^{\circ} \mathrm{C}$ until its utilization, and their dilutions were cultivated in solid medium to verify the absence of contamination and inoculum growth. The essential oil was dissolved $\left(0.1-100 \mathrm{mg} \mathrm{mL}^{-1}\right)$ in aqueous solution of $50 \mathrm{~mL} \mathrm{~L}^{-1}$ DMSO with $1 \mathrm{mg}$ $\mathrm{mL}^{-1}$ polysorbate- 80 and added to Luria-Bertani (LB) 
cultivation medium $(100 \mu \mathrm{L})$ with bacterial inoculum $\left(1.0 \times 10^{4} \mathrm{CFU}\right.$ per well) to obtain the desired concentrations. The microplates were incubated in a rotary agitator $(160 \mathrm{rpm})$ for $24 \mathrm{~h}$ at $37^{\circ} \mathrm{C}$. The MIC was defined as the lowest concentration without visible growth of the microbial biomass under optic microscope. The minimum bactericidal concentration (MBC) was determined by a serial subcultivation of 2 $\mu \mathrm{L}$ in microtiter plates containing $100 \mu \mathrm{L}$ LB per well, and incubated for $24 \mathrm{~h}$. The lowest essential oil concentration, without visible growth under optical microscope, was defined as $\mathrm{MBC}$, indicating $99.5 \%$ of death of the original inoculum. The optical density of each well was measured at $655 \mathrm{~nm}$ in a Microplate manager 4.0 (Bio-Rad Laboratories) and compared to positive controls. The negative control was an aqueous solution of $50 \mathrm{~mL} \mathrm{~L}^{-1}$ DMSO, and the positive controls $\left(1 \mathrm{mg} \mathrm{mL}^{-1}\right.$ in sterile saline solution) were the commercial antibiotics streptomycin (Sigma P7794) and ampicillin (Panfarma, Belgrade, Serbia), and the food additives E221 and E224 (GarciaFuentes et al., 2015) from 0.001 to $3.5 \mathrm{mg} \mathrm{mL}^{-1}$.

\section{Statistical analysis}

The antimicrobial assays were carried out in duplicate with three replications. The results were expressed in arithmetical average \pm standard deviation, and analyzed by unidirectional analysis of variance (ANOVA) followed by Tukey's HSD (honestly significant difference) test with $\alpha=0.05$ to determine the statistical significance of the results. The analysis was done using Statistica ${ }^{\circledR} 8.0$ software.

\section{RESULTS}

\section{Essential oil yield and chemical composition}

The essential oil yield from $P$. cattleianum dried leaves was $0.83 \%$. A gas chromatography analysis showed 68 compounds, and 60 out of them were identified. The major class was hydrocarbon sesquiterpenes $(47.6 \%)$ and the major identified were trans- $\beta$-caryophyllene (14.7\%), 1,8-cineole $(11.7 \%)$, y-muurolene $(5.6 \%), \alpha$-santalol $(4.7 \%)$, globulol $(4.7 \%), \delta$-selinene $(4.5 \%)$, and $\delta$-cadinene $(4.1 \%)$ (Table No. 1).

Table No. 1

GC-MS chemical composition from the essential oil of Psidium cattleianum leaves

\begin{tabular}{|c|c|c|c|c|c|}
\hline Peak & ${ }^{\mathrm{a} C o m p o u n d s}$ & $\begin{array}{l}\text { Relative } \\
\text { area } \\
(\%)\end{array}$ & $\begin{array}{c}{ }^{\mathbf{b}} \mathbf{R I} \\
\text { calculate } \\
\mathbf{d}\end{array}$ & $\begin{array}{c}{ }^{\mathbf{c}} \mathbf{R I} \\
\text { theoretic } \\
\text { al }\end{array}$ & $\begin{array}{l}\text { Methods of } \\
\text { identification }\end{array}$ \\
\hline 1 & 2-thujene & 0.18 & 925 & 924 & $a, b, c$ \\
\hline 2 & $\alpha$-pinene & 3.13 & 933 & 932 & $a, b, c$ \\
\hline 3 & $\beta$-pinene & 0.25 & 974 & 974 & $\mathrm{a}, \mathrm{b}, \mathrm{c}$ \\
\hline 4 & $\beta$-myrcene & 0.71 & 987 & 988 & $a, b, c$ \\
\hline 5 & $\alpha$-phellandrene & 0.12 & 1001 & 1002 & $a, b, c$ \\
\hline 6 & $\delta$-3-carene & 0.07 & 1007 & 1001 & $\mathrm{a}, \mathrm{b}, \mathrm{c}$ \\
\hline 7 & $\alpha$-terpinene & 0.21 & 1014 & 1014 & $a, b, c$ \\
\hline 8 & o-cymene & 1.40 & 1026 & 1022 & $a, b, c$ \\
\hline 9 & 1,8-cineole & 11.70 & 1035 & 1026 & $a, b, c$ \\
\hline 10 & Trans- $\beta$-ocimene & 1.15 & 1038 & 1044 & $\mathrm{a}, \mathrm{b}, \mathrm{c}$ \\
\hline 11 & Cis- $\beta$-ocimene & 0.32 & 1046 & 1032 & $a, b, c$ \\
\hline 12 & X-terpinene & 1.41 & 1058 & 1054 & $a, b, c$ \\
\hline 13 & n.i. & 0.33 & - & - & $\mathrm{a}$ \\
\hline 14 & Terpinolene & 0.15 & 1085 & 1086 & $a, b, c$ \\
\hline 15 & Linalool & 2.03 & 1098 & 1095 & $a, b, c$ \\
\hline 16 & n.i. & 0.17 & - & - & $\mathrm{a}$ \\
\hline 17 & n.i. & 0.06 & - & - & $\mathrm{a}$ \\
\hline 18 & Trans- $\beta$-terpineol & 0.71 & 1174 & 1159 & $a, b, c$ \\
\hline 19 & $\alpha$-terpineol & 2.78 & 1189 & 1186 & $a, b, c$ \\
\hline 20 & n.i. & 0.38 & - & - & $\mathrm{a}$ \\
\hline 21 & $\alpha$-ylangene & 0.14 & 1364 & 1373 & $a, b, c$ \\
\hline
\end{tabular}

Boletín Latinoamericano y del Caribe de Plantas Medicinales y Aromáticas/617 


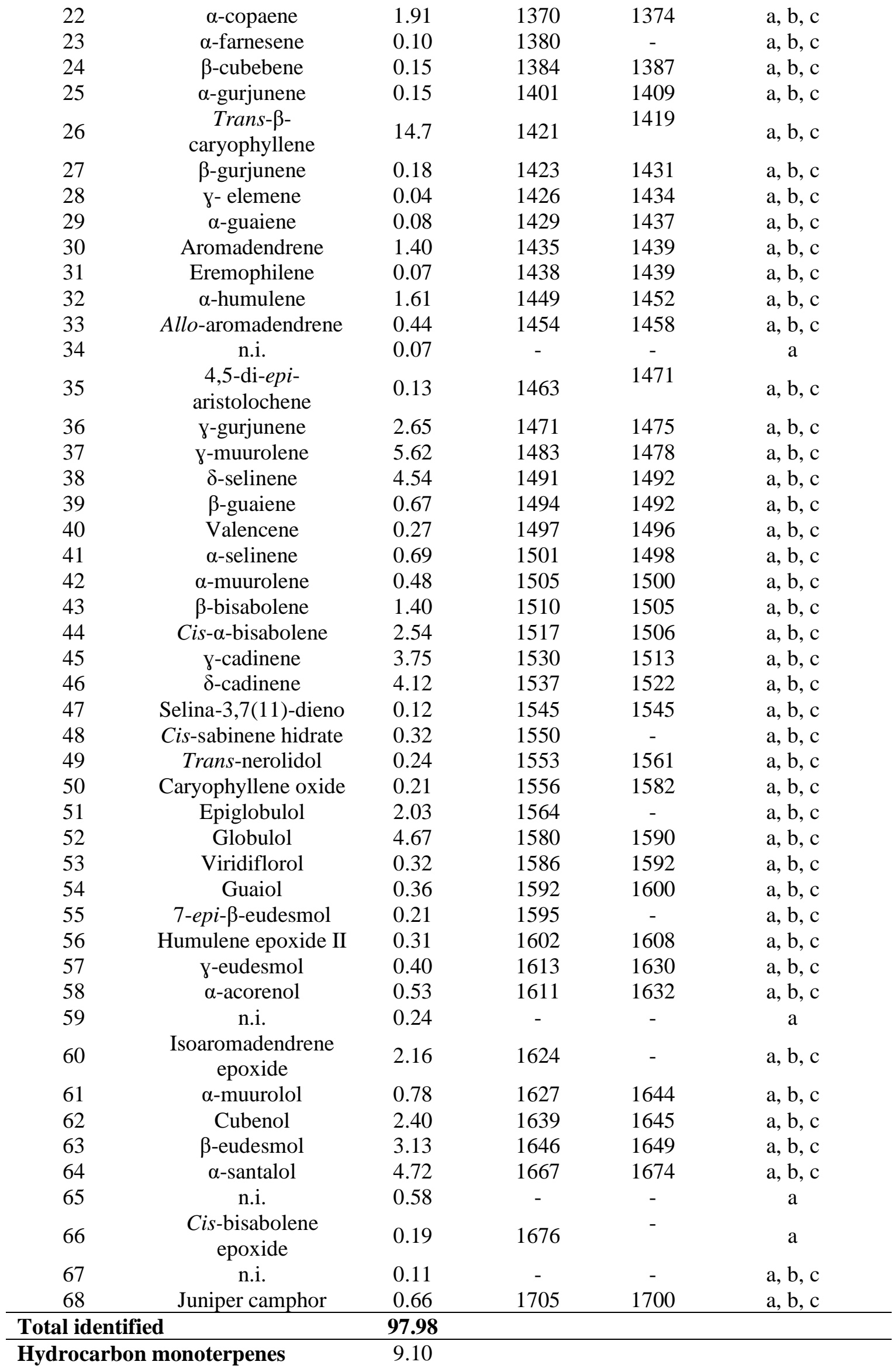


Oxygenated monoterpenes Hydrocarbon sesquiterpenes Oxygenated sesquiterpenes n.i.

Total
17.97

47.61

23.30

1.94

99.92

${ }^{\mathrm{a}}$ Compounds listed in elution order in HP-5MS UI column; ${ }^{\mathrm{b}} \mathrm{RI}=$ identification based on the calculated retention index (RI) utilizing a standard homologous series of $n$-alkanes $\mathrm{C}_{7}-\mathrm{C}_{28}$ in Agilent HP-5MS UI column; ${ }^{\mathrm{RI}}$ theoretical, identification based on the comparison of mass spectra found in NIST 11.0 libraries (Adams, 2017); Relative area (\%): percentage of the area occupied by the compounds in the chromatogram; n.i. = non-identified; (-) not found

\section{Antifungal activity of the essential oil}

The MIC values for the essential oil varied from 0.17 to $11.25 \mathrm{mg} \mathrm{mL}^{-1}$; for bifonazole and ketoconazole widely used fungicides (Gupta et al., 1994) - the values ranged from 0.10 to $0.20 \mathrm{mg} \mathrm{mL}^{-1}$ and from 0.20 to $2.50 \mathrm{mg} \mathrm{mL}^{-1}$, respectively, whereas for E221 and E224 - main used food additives to control microorganisms (Garcia-Fuentes et al., 2015) - the MIC values ranged from 1.00 to $2.00 \mathrm{mg} \mathrm{mL}^{-1}$ and from 0.50 to $1.00 \mathrm{mg} \mathrm{mL}^{-1}$, respectively (Table No. $2)$. The MIC value of the essential oil for $A$. fumigatus was similar to bifonazole $(p>0.05)$, and 1.2 -fold lower $(p \leq 0.05)$ than ketoconazole. The MIC values of the essential oil for $A$. ochraceus, $A$. versicolor, and $T$. viride were 3-, 6-, and 4-fold lower $(p \leq 0.05)$ than E221, respectively, and 3-, 3-, and 4fold lower than E224, respectively (Table No. 2). The fungistatic activity of the essential oil against $A$. fumigatus, A. ochraceus, A. versicolor, and $T$. viride indicates high antimicrobial activity of the essential oil. Although the essential oil showed fungistatic activity against $A$. niger, $P$. funiculosum, $P$. ochrochloron, and $P$. verrucosum, the MIC values were higher than for those obtained for all positive controls (Table No. 2). It indicates that the first group of fungi was more sensitive than the second group to low concentrations of the essential oil, mainly $A$. fumigatus, and it could be used as a selective fungicide for the former.

The fungicidal activity of the essential oil had MFC values ranging from 0.23 to $22.50 \mathrm{mg} \mathrm{mL}^{-1}$; for bifonazole they ranged from 0.20 to $0.25 \mathrm{mg} \mathrm{mL}^{-1}$; for ketoconazole the values were from 0.30 to 3.50 $\mathrm{mg} \mathrm{mL}^{-1}$ whereas for E221 and E224 they were from 1.00 to $4.00 \mathrm{mg} \mathrm{mL}^{-1}$, and from 0.50 to $2.00 \mathrm{mg} \mathrm{mL}^{-1}$, respectively (Table No. 2). The essential oil MFC value for $A$. fumigatus was similar $(p>0.05)$ to bifonazole, and 2.2-fold lower $(p \leq 0.05)$ than ketoconazole while it was 8.7- and 4.3-fold lower $(p \leq 0.05)$ than E221 and E224, respectively (Table No. 2). In addition, the MFC values of the essential oil for A. ochraceus, A. versicolor, and T. viride were higher $(p \leq 0.05)$ than bifonazole, but still lower than $(p \leq 0.05)$ or similar to $(p>0.05)$ ketoconazole, E221, and E224 (Table No. 2). The MFC values of the essential oil for $A$. ochraceus and $A$. versicolor ranged from 2.2- to 4.3-fold lower than the food additive controls, and for $T$. viride the values were 1.1-fold lower than E221, and 0.5 higher than E224. It indicates that the essential oil was a very effective and selective fungicide to control A. fumigatus, $A$. ochraceus, A. versicolor, and $T$. viride at low concentrations compared to all positive controls.

\section{Antibacterial activity of the essential oil}

The MIC values for the essential oil ranged from 1.40 to $16.87 \mathrm{mg} \mathrm{mL}^{-1}$; for streptomycin and ampicillin they ranged from 0.04 to $0.25 \mathrm{mg} \mathrm{mL}^{-1}$ and from 0.25 to $0.75 \mathrm{mg} \mathrm{mL}^{-1}$, respectively; while the MIC values ranged from 1.00 to $4.00 \mathrm{mg} \mathrm{mL}^{-1}$ and from 0.5 to 1.0 $\mathrm{mg} \mathrm{mL}^{-1}$ for E221 and E224, respectively (Table No. $3)$. The lowest MIC values obtained for the essential oil were against $P$. aeruginosa, B. cereus, and $S$. aureus (Table No. 3). The MIC values of the essential oil were in general higher than the controls, except for E221 that were 1.4- and 1.9-fold lower for $P$. aeruginosa and $S$. aureus, respectively. It suggests that the essential oil has potential use to control these bacteria. Although the essential oil showed bacteriostatic activity against the other bacteria, the MIC values were much higher than the controls, indicating that this essential oil was less promising to control E. cloacae, E. coli, L. monocytogenes, M. luteus, and S. enterica.

The bactericidal activity of the essential oil ranged from 2.81 to $22.50 \mathrm{mg} \mathrm{mL}^{-1}$; the $\mathrm{MBC}$ values for streptomycin and ampicillin varied from 0.10 to $0.50 \mathrm{mg} \mathrm{mL}^{-1}$ and from 0.40 to $1.20 \mathrm{mg} \mathrm{mL}^{-1}$, respectively; while for E221 and E224 these values ranged from 2.00 to $4.00 \mathrm{mg} \mathrm{mL}^{-1}$ and from 0.50 to $2.00 \mathrm{mg} \mathrm{mL}^{-1}$, respectively (Table No. 3). The lowest MBC values obtained for the essential oil were also against $P$. aeruginosa, B. cereus, and $S$. aureus (Table No. 3). The MBC values of the essential oil 
were in general higher than controls, except for E221 that were 1.4-fold lower for $P$. aeruginosa and $S$. aureus, respectively. It suggests that the essential oil has potential use to strongly inhibit these bacteria. Although the essential oil showed bactericidal activity against the other bacteria, the $\mathrm{MBC}$ values were much higher than the controls, indicating that this essential oil was less promising to inhibit $E$. cloacae, E. coli, L. monocytogenes, M. luteus, and $S$. enterica.

Table No. 2

Minimum inhibitory concentration (MIC) and minimum fungicidal concentration (MFC) from Psidium cattleianum (red fruit) leaf essential oil and positive controls bifonazole, ketoconazole, sodium sulphite

(E221), and potassium metabisulphite (E224)

\begin{tabular}{|c|c|c|c|c|c|}
\hline \multirow{3}{*}{ Fungus } & $\begin{array}{c}\text { essential oil } \\
\left(\mathrm{mg} \mathrm{mL}^{-1}\right)\end{array}$ & $\begin{array}{l}\text { bifonazole } \\
\left(\mathrm{mg} \mathrm{mL}^{-1}\right)\end{array}$ & $\begin{array}{c}\text { ketoconazole } \\
\left(\mathbf{m g ~ m} \mathbf{L}^{-1}\right)\end{array}$ & $\begin{array}{c}\text { E221 } \\
\left(\mathrm{mg} \mathrm{mL}^{-1}\right)\end{array}$ & $\begin{array}{c}\mathbf{E 2 2 4} \\
\left(\mathrm{mg} \mathrm{mL}^{-1}\right)\end{array}$ \\
\hline & MIC & MIC & MIC & MIC & MIC \\
\hline & MFC & MFC & MFC & MFC & MFC \\
\hline \multirow{2}{*}{ A. fumigatus } & $0.17 \pm 0.02^{\mathrm{a}}$ & $0.15 \pm 0.02^{\mathrm{a}}$ & $0.20 \pm 0.02^{\mathrm{b}}$ & $1.00 \pm 0.02^{\mathrm{c}}$ & $1.00 \pm 0.02^{\mathrm{c}}$ \\
\hline & $0.23 \pm 0.03^{\mathrm{a}}$ & $0.20 \pm<0.01^{\mathrm{a}}$ & $0.50 \pm 0.03^{b}$ & $2.00 \pm 0.01^{\mathrm{d}}$ & $1.00 \pm 0.03^{c}$ \\
\hline \multirow{2}{*}{ A. ochraceus } & $0.34 \pm 0.03^{\mathrm{b}}$ & $0.15 \pm 0.03^{\mathrm{a}}$ & $1.50 \pm 0.20^{\mathrm{d}}$ & $1.00 \pm 0.03^{c}$ & $1.00 \pm 0.20^{\mathrm{c}}$ \\
\hline & $0.46 \pm 0.03^{b}$ & $0.20 \pm 0.02^{\mathrm{a}}$ & $2.00 \pm 0.30^{\mathrm{d}}$ & $1.00 \pm 0.02^{\mathrm{c}}$ & $2.00 \pm 0.30^{\mathrm{d}}$ \\
\hline \multirow{2}{*}{ A. niger } & $11.25 \pm 0.10^{c}$ & $0.15 \pm 0.04^{\mathrm{a}}$ & $0.20 \pm 0.02^{\mathrm{a}}$ & $1.00 \pm 0.04^{\mathrm{b}}$ & $1.00 \pm 0.02^{b}$ \\
\hline & $22.50 \pm 0.10^{\mathrm{e}}$ & $0.20 \pm 0.06^{\mathrm{a}}$ & $0.50 \pm<0.01^{b}$ & $2.00 \pm 0.06^{\mathrm{d}}$ & $1.00 \pm 0.01^{\mathrm{c}}$ \\
\hline \multirow{2}{*}{ A. versicolor } & $0.34 \pm 0.02^{c}$ & $0.10 \pm<0.01^{\mathrm{a}}$ & $0.20 \pm 0.06^{\mathrm{b}}$ & $2.00 \pm 0.01^{\mathrm{e}}$ & $1.00 \pm 0.06^{\mathrm{d}}$ \\
\hline & $0.46 \pm 0.06^{\mathrm{b}}$ & $0.20 \pm 0.03^{\mathrm{a}}$ & $0.50 \pm 0.02^{\mathrm{b}}$ & $2.00 \pm 0.03^{\mathrm{d}}$ & $1.00 \pm 0.02^{\mathrm{c}}$ \\
\hline \multirow{2}{*}{ P. funiculosum } & $11.25 \pm 0.10^{\mathrm{d}}$ & $0.20 \pm 0.02^{\mathrm{a}}$ & $0.20 \pm 0.02^{\mathrm{a}}$ & $1.00 \pm 0.02^{\mathrm{c}}$ & $0.50 \pm 0.02^{b}$ \\
\hline & $22.50 \pm 0.20^{\mathrm{d}}$ & $0.25 \pm 0.06^{\mathrm{a}}$ & $0.50 \pm 0.06^{\mathrm{b}}$ & $2.00 \pm 0.06^{\mathrm{c}}$ & $0.50 \pm 0.06^{b}$ \\
\hline \multirow{2}{*}{ P. ochrochloron } & $11.25 \pm 0.10^{\mathrm{d}}$ & $0.20 \pm 0.01^{\mathrm{a}}$ & $2.50 \pm 0.30^{\mathrm{c}}$ & $2.00 \pm 0.10^{c}$ & $0.50 \pm 0.30^{\mathrm{b}}$ \\
\hline & $22.50 \pm 0.06^{\mathrm{e}}$ & $0.25 \pm 0.06^{\mathrm{a}}$ & $3.50 \pm 0.60^{\mathrm{d}}$ & $2.00 \pm 0.06^{\mathrm{c}}$ & $1.00 \pm 0.06^{\mathrm{b}}$ \\
\hline \multirow{2}{*}{ P. verrucosum } & $8.40 \pm 0.60^{\mathrm{e}}$ & $0.10 \pm 0.02^{\mathrm{a}}$ & $0.20 \pm 0.03^{\mathrm{b}}$ & $2.00 \pm 0.02^{\mathrm{d}}$ & $1.00 \pm 0.03^{\mathrm{c}}$ \\
\hline & $11.25 \pm 0.03^{\mathrm{e}}$ & $0.20 \pm 0.03^{\mathrm{a}}$ & $0.30 \pm 0.02^{b}$ & $4.00 \pm 0.03^{d}$ & $1.00 \pm 0.02^{\mathrm{c}}$ \\
\hline \multirow{2}{*}{ T. viride } & $0.23 \pm 0.03^{\mathrm{b}}$ & $0.15 \pm 0.03^{\mathrm{a}}$ & $1.00 \pm 0.20^{\mathrm{c}}$ & $1.00 \pm 0.03^{c}$ & $1.00 \pm 0.20^{\mathrm{c}}$ \\
\hline & $1.87 \pm 0.06^{c}$ & $0.20 \pm<0.01^{\mathrm{a}}$ & $1.00 \pm 0.20^{\mathrm{b}}$ & $2.00 \pm 0.01^{\mathrm{d}}$ & $1.00 \pm 0.20^{\mathrm{b}}$ \\
\hline
\end{tabular}

*Averages followed by different letters in the same row for MIC or for MFC differ by Tukey's HSD (honestly significant difference) test ( $\boldsymbol{p} \leq \mathbf{0 . 0 5})$. Aspergillus fumigatus; Aspergillus niger; Aspergillus ochraceus; Aspergillus versicolor; Penicillium funiculosum; Penicillium ochrochloron; Penicillium verrucosum var. cyclopium; Trichoderma viride

Overall, the essential oil from $P$. cattleianum leaves showed fungistatic, fungicidal, bacteriostatic, and bactericidal activities. In addition, the essential oil had inhibitive selective action among microorganisms at different concentrations, and it could be used in studies where it is necessary to inhibit one microorganism at the expense of another, by adding the essential oil in the cultivation medium to make it a selective medium. 
Table No. 3

Minimum inhibitory concentration (MIC) and minimum bactericidal concentration (MBC) from Psidium cattleianum (red fruit) leaf essential oil and positive controls streptomycin, ampicillin, sodium sulphite (E221), and potassium metabisulphite (E224)

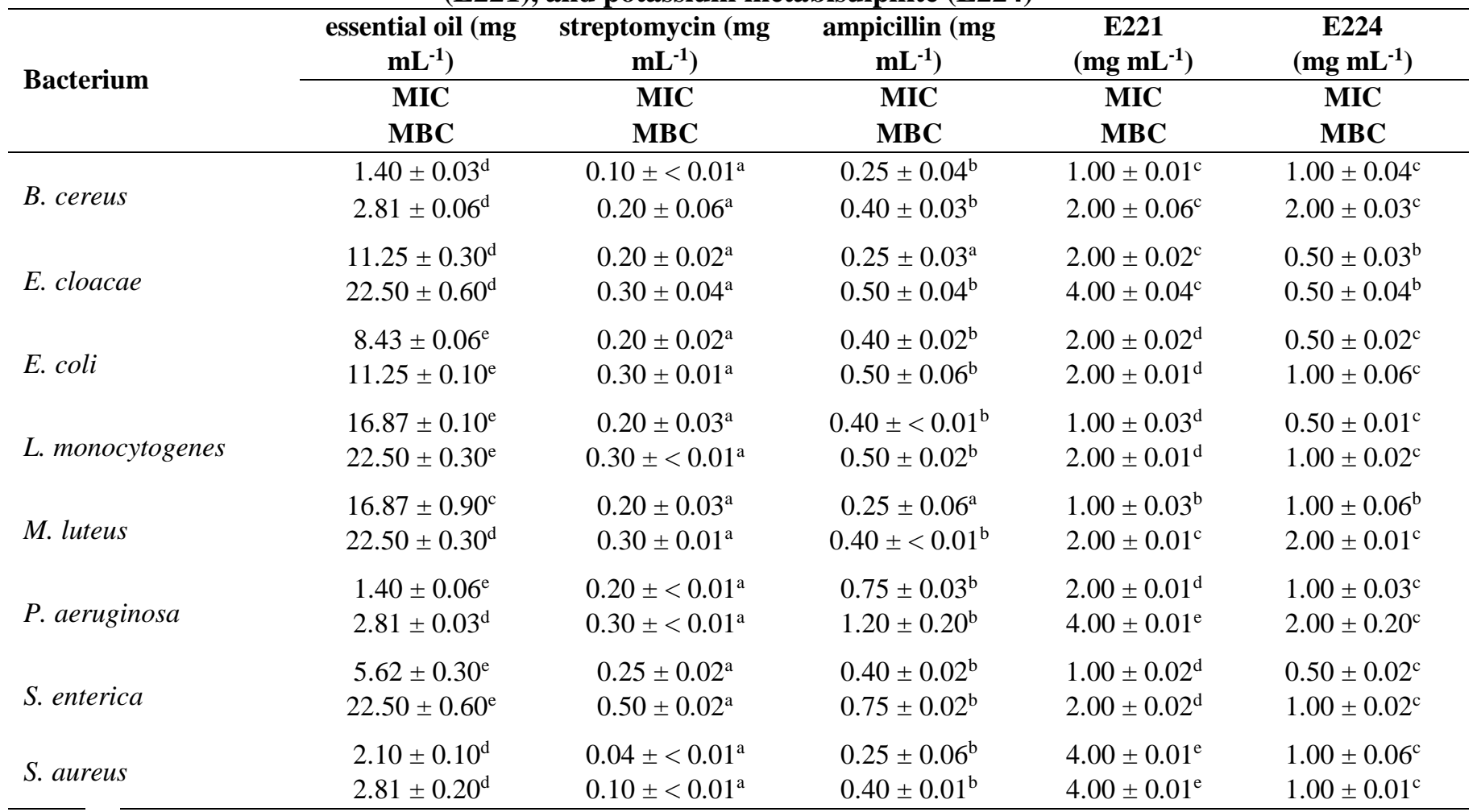

*Averages followed by different letters in the same row for MIC or for MFC differ by Tukey's HSD (honestly significant difference) test ( $p \leq \mathbf{0 . 0 5})$. Bacillus cereus; Enterobacter cloacae; Escherichia coli; Listeria monocytogenes; Micrococcus luteus; Pseudomonas aeruginosa; Salmonella enterica subsp. enterica; Staphylococcus aureus

\section{DISCUSSION}

Essential oil yields can vary in function of the genetic, regional, and climatic characteristics of the plant (Baser \& Buchbauer, 2010). The essential oil yield from $P$. cattleianum dried leaves has been reported to range from 0.51 to $0.76 \%$ (Apel et al., 2006; Chalannavar et al., 2013; Oh et al., 2014; Pino et al., 2004). This range is close to the yield obtained in our study $(0.83 \%)$. The essential oil yield obtained in our study was $8.3 \mathrm{~mL} \mathrm{~kg}^{-1}$ (dry material), a much greater value than the reference of $2 \mathrm{~mL} \mathrm{~kg}^{-1}$ (dry material) considered necessary to develop an industrial application according to the European Pharmacopoeia (2013).

The chemical variation of the compounds and their concentrations in plants can be related to factors such as genetic variability, environmental aspects, growth conditions, and soil type (Morais \& Castanha, 2012). The characterization of the chemical compounds depends on the response to the conditions in each ecosystem, and therefore, $P$. cattleianum could produce different volatile metabolites (Table No. 4). Chalannavar et al. (2013) observed that the dried-leaf essential oil of $P$. cattleianum in the southern region of Africa presented oxygenated sesquiterpenes $(36.8 \%)$ as the major class, and caryophyllene oxide $(12.4 \%)$ as the major compound. Soliman et al. (2016) reported that the essential oil from $P$. cattleianum leaves in Egypt presented $\beta$-caryophyllene $(28.8 \%)$ as the major compound of the sesquiterpene class. This result is in accordance to the ones found in our study in which the major compounds were trans- $\beta$-caryophyllene $(14.7 \%)$ and 1,8-cineole (11.7\%). For the dried-leaf essential oil of $P$. cattleianum in Cuba, Pino et al. (2004) found as the major compounds epi- $\alpha$-muurolol $(21.9 \%)$ and $\alpha$-cadinol $(20.0 \%)$. The chemical characterization of essential oils from different sources may well serve as a good reference for the analysis of biological activities of $P$. cattleianum. 
Table No. 4

Major compounds from leaf essential oil of Psidium cattleianum (red fruit) obtained by hydrodistillation

\begin{tabular}{|c|c|c|}
\hline Compound & Amount (\%) & Source \\
\hline trans- $\beta$-caryophyllene & 14.7 & \\
\hline 1,8-cineole & 11.7 & (Data from our study) \\
\hline y-muurolene & 5.6 & \\
\hline Caryophyllene oxide & 12.4 & \multirow{4}{*}{ (Chalannavar et al., 2012) } \\
\hline Bicyclo(4.4.0)dec-I-ene & 6.6 & \\
\hline 2,3-butadnediol diacetate & 4.8 & \\
\hline Patchoulene & 4.7 & \\
\hline Caryophyllene oxide & 29.6 & \multirow{4}{*}{ (Chalannavar et al., 2013) } \\
\hline Alloaromadendrene oxide-(1) & 6.8 & \\
\hline 12-oxabicyclo[9.1.0] dodeca-3,7-diene & 5.8 & \\
\hline $1 \mathrm{H}$-cycloprop[e]azulene & 3.5 & \\
\hline Isocaryophyllene & 59.6 & \multirow{4}{*}{ (Castro et al., 2015) } \\
\hline Caryophyllene oxide & 18.2 & \\
\hline$\alpha$-caryophyllene & 6.4 & \\
\hline Cadimol & 4.6 & \\
\hline Epi- $\alpha$-muurolol & 21.9 & \multirow{4}{*}{ (Pino et al., 2004) } \\
\hline$\alpha$-cadinol & 20.0 & \\
\hline Epi- $\alpha$-cadinol & 16.7 & \\
\hline Caryophyllene oxide & 13.6 & \\
\hline$\alpha$-thujene & 25.2 & \multirow{3}{*}{ (Marques et al., 2008) } \\
\hline 1,8-cineole & 16.4 & \\
\hline$\beta$-caryophyllene & 10.2 & \\
\hline$\alpha$-copaene & 22.0 & \multirow{4}{*}{ (Scur et al., 2016) } \\
\hline Eucalyptol & 15.0 & \\
\hline$\delta$-cadinene & 9.6 & \\
\hline$\alpha$-selinene & 6.5 & \\
\hline
\end{tabular}

The factors that interfere in the chemical composition and major compounds of $P$. cattleianum essential oil also affect the antimicrobial activity. Scur et al. (2016) reported that $P$. cattleianum leaf essential oil presented $\alpha$-copaene $(22 \%)$ and eucalyptol $(15 \%)$ as major compounds, and the antibacterial activity against $P$. aeruginosa and $S$. aureus showed a MBC value of $200 \mathrm{mg} \mathrm{mL}^{-1}$ for both strains. In our study, trans- $\beta$-caryophyllene (14.7\%) and 1,8 -cineole $(11.7 \%)$ were the major compounds, and the MBC values were approximately 70 times lower for the same microorganisms, suggesting greater antibacterial activity efficacy of the essential oil at lower concentration.

The major compounds observed in our study were also described for other plants of the Psidium genus and the Myrtaceae family. Essential oils from Psidium guajava leaves showed great variation of $\beta$ caryophyllene concentration, ranging from $16.1 \%$ (Silva et al., 2019) to 20.3\% (Arain et al., 2019). Chen et al., (2007) reported $\beta$-caryophyllene (27.7\%) followed by 1,8 -cineole $(12.4 \%)$ from the essential oil of $P$. guajava leaves. The chemical composition of the essential oil from $P$. myrtoides leaves had 1,8cineole as the major compound, varying from 29.8 to $48.1 \%$, due to the effect of the sazonal harvest period (Macêdo et al. 2020). Also, y-muuruleno has been reported as a minor compound $(0.7 \%)$ in Psidium myrsinites (Medeiros et al., 2015).

Trans- $\beta$-caryophyllene is a bicyclic hydrocarbon sesquiterpene that presents several biological properties against diseases like cancer (Di 
Giacomo et al., 2017), cardio protective characteristics against myocardium infarction (Younis et al., 2019), and anti-inflammatory activity (Benitez et al., 2009). The Research Institute for Fragrance Materials (RIFM) evaluated it as safe, and the Food and Drug Administration (FDA) in the USA approved the use of trans- $\beta$-caryophyllene as an aromatic agent in cosmetics products and in food additives (Api et al., 2018). Also, $\beta$-caryophyllene isolated from Murraya paniculata has shown antibacterial activity against $S$. aureus (ATCC 25923), Salmonella typhimurium (ATCC 14028), E. coli (ATCC 8739), and Enterococcus faecalis (ATCC 14506) with $\mathrm{MBC}$ ranging from 2.0 to $4.0 \mathrm{mg} \mathrm{mL}^{-1}$, and antifungal activity against $A$. niger (ATCC 40067), A. fumigatus (ATCC 40014), A. parasiticum (ATCC 40100), and Fusarium solani (ATCC 40099) with MFC ranging from 0.5 to $4.0 \mathrm{mg} \mathrm{mL}^{-1}$ (Neta et al., 2017). In our study, the essential oil showed a similar MBC value of $2.18 \mathrm{mg} \mathrm{mL}-1$ against $S$. aureus, and a lower MFC value of $0.23 \mathrm{mg} \mathrm{mL}^{-1}$ against A. fumigatus, indicating greater efficacy of the essential oil.

Among the oxygenated monoterpenes, 1,8cineole, the second major compound in our study, also known as eucalyptol, is a bicyclic monoterpene and the main compound in the essential oils from Eucalyptus, Rosmarinus, Psidium, Croton, and Salvia genera (Kovar et al., 1987; Manoel et al., 1994; Farhat et al., 2001). Several biological and pharmacological activities have been reported for this compound such as anti-inflammatory (Santos \& Rao, 2000), anticancer (Rodenak-Kladniew et al., 2020), and antifungal (Vilela et al., 2009) activities. Vuuren et al. (2007) reported that 1,8-cineole (SigmaAldrich) presented antibacterial activity against $S$. aureus $\left(\mathrm{MIC}=8 \mathrm{mg} \mathrm{mL}^{-1}\right.$ ), B. cereus $(\mathrm{MIC}=2 \mathrm{mg}$ $\left.\mathrm{mL}^{-1}\right)$, E. coli $\left(\mathrm{MIC}=8 \mathrm{mg} \mathrm{mL}^{-1}\right.$ ), and $P$. aeruginosa $\left(\mathrm{MIC}=4 \mathrm{mg} \mathrm{mL}^{-1}\right)$. These values are similar or lower than the ones obtained in our study for the same species with MIC ranging from 1.40 to $8.43 \mathrm{mg}$ $\mathrm{mL}^{-1}$. This indicates that the essential oil shows more antibacterial activity than the isolated compounds, suggesting the synergistic effect among the essential oil compounds in the present study. In addition, Sun et al. (2018) studied the antibacterial mechanism of 1,8-cineole in the genus Salmonella, and observed that $2.5 \mathrm{mg} \mathrm{mL}-1$ of this compound in ethanol modified the metabolism of carbohydrates and the genes related to ompF, ompD, yidC, lpp1, mraY, murD and skp of membrane proteins. The antifungal activity of 1,8-cineole (Sigma-Aldrich) was also reported against Candida albicans with MIC of $8 \mathrm{mg}$ $\mathrm{mL}^{-1}$ and MFC of $64 \mathrm{mg} \mathrm{mL}^{-1}$ (Hendry et al., 2009). This suggests that, despite the antifungal activity found in our study at high concentrations, it was more efficient than the isolated compound. In our study, the compounds trans- $\beta$-caryophyllene and 1,8cineole found in the leaves represents $26.4 \%$ of the essential oil mixture, and are probably the main antimicrobial agents, showing that the essential oil with this composition is a promising alternative to control microorganisms.

In the website of PubChem (Open Chemistry Database at the National Institutes of Health, USA), $\gamma$-muurolene and $\alpha$-santalol are cited as general flavoring agents used in foods, including condiments, and seasonings; globulol is cited as anxiolytic, antipsychotic, neuroleptic, and a drug for schizophrenia, whereas $\delta$-selinene and $\delta$-cadinene are cited as surfactants and emulsifiers (PubChem, 2020a; PubChem, 2020b; PubChem, 2020c; PubChem, 2020d; PubChem, 2020e). These sesquiterpenes can potentialize the antimicrobial activity of the essential oil promoting the permeability of the microbial membranes (Bakkali et al., 2008).

Our studies showed that $P$. cattleianum essential oil presents bactericidal activity, mainly against $B$. cereus, $S$. aureus, and $P$. aeruginosa, important pathogenic bacteria in public health. $S$. aureus is one of responsible for the most common pathogenic infections of Gram-positive bacteria in humans (Tong et al., 2015), with resistance to several antibiotics around the world (Widianingrum et al., 2019). P. aeruginosa is a pathogenic Gram-negative agent, and a common foodborne pathogen that can develop resistance to conventional antimicrobials and represents a serious threat to public health, mainly because it could cause bloodstream infections (Paramythiotou \& Routsi, 2016). B. cereus is a Gram-positive bacterium that causes foodborne outbreaks, frequently associated with diarrheal and emetic syndromes (Zhu et al., 2016).

Sivakumar \& Bautista-Baños (2014) and Burt (2004) recommended that the use of essential oils to preserve food must be at concentrations from 0.1 to $6 \%$ (mass/mass). The fungicide concentrations of the leaf essential oil of $P$. cattleianum in our study ranged from 0.23 to $22.50 \mathrm{mg} \mathrm{mL}^{-1}$ (equivalent to 0.2 to $2.2 \%$, respectively). Therefore, the essential oil concentrations that showed antimicrobial activity in our study are in the range suggested as food preservative, making the essential oil from $P$. 
cattleianum leaves an alternative for utilization in foods, as long as it has no cytotoxicity. Castro et al. (2015) evaluated the acute toxicity potential of the leaf essential oil of $P$. cattleianum on mice and showed that $500 \mathrm{mg} \mathrm{kg}^{-1}$ (body mass) was not lethal or caused body mass reduction. Although the $\mathrm{LD}_{50}$ is not documented in this study, given the variations in chemical composition of the essential oils obtained from different locations, toxicity studies must be evaluated for each mixture and their safety established, prior to its development to prevent foodborne diseases.

\section{CONCLUSION}

The essential oil yield from $P$. cattleianum leaves was $0.83 \%$, and showed 60 compounds, mainly hydrocarbon sesquiterpenes $(47.6 \%)$. The major compounds identified were trans- $\beta$-caryophyllene $(14.7 \%)$ and 1,8-cineole (11.7\%), followed by $\mathrm{\gamma}$ muurolene $(5.6 \%), \alpha$-santalol $(4.7 \%)$, globulol $(4.7 \%), \delta$-selinene $(4.5 \%)$, and $\delta$-cadinene $(4.1 \%)$.
The essential oil showed antimicrobial activity against all tested fungi and bacteria. The most promising fungicidal activities were against $A$. fumigatus, A. ochraceus, A. versicolor, and $T$. viride, and the bactericidal activities against $P$. aeruginosa, $B$. cereus, and $S$. aureus. The toxicity studies of the essential oil will support its development as a food preservative to control foodborne diseases.

\section{ACKNOWLEDGEMENTS}

The authors thank Paranaense University, UniCesumar University, University of Belgrade, Fundação Araucária, Conselho Nacional de Desenvolvimento Científico e Tecnológico (CNPq), and Coordenação de Aperfeiçoamento de Pessoal de Nível Superior - Brasil (CAPES) -finance code 001and Ministry of Education, Science and Technological Development of Republic of Serbia (451-03-68/2020-14/200007) for the financial support and scholarships.

\section{REFERENCES}

Adams RP. 2017. Identification of essential oil components by gas chromatography/mass spectrometry. 5th ed. Texensis Publishing, Gruver, TX, USA.

Andreotti R, Nicodemo MLF. 2004. Uso de antimicrobianos na produção de bovinos e desenvolvimento da resistência. Documentos 144. Empresa Brasileira de Pesquisa Agropecuária Centro Nacional de Pesquisa. Embrapa Gado de Corte, Campo Grande, MS, Brasil. http://ainfo.cnptia.embrapa.br/digital/bitstream/item/104772/1/Uso-de-antimicrobianos.pdf

Apel MA, Lima MEL, Souza A, Cordeiro I, Young MCM, Sobral MEG, Suffredini IB, Moreno PRH. 2006. Screening of the biological activity from essential oils of native species from the Atlantic rain forest (São Paulo - Brazil). Pharmacologyonline 3: 376 - 383.

Api AM, Belsito D, Botelho D, Bruze M, Burton GA, Buschmann J, Dagli ML, Date M, Dekant W, Deodhar C, Francis M, Fryer A, Jones L, Joshi K, La Cava S, Lapczynski A, Liebler DC, O'Brien D, Patel A, Penning TM, Ritacco G, Romine J, Sadekar N, Salvito D, Schultz TW, Sipes IG, Sullivan G, Thakkar Y, Tokura Y, Tsang S. 2018. RIFM fragrance ingredient safety assessment, $\beta$-caryophyllene alcohol, CAS registry number 472-97-9. Food Chem Toxicol 122: 566 - 572. https://doi.org/10.1016/j.fct.2018.10.020

Arain A, Sherazi STH, Mahesar SA, Sirajuddin. 2019. Essential oil from Psidium guajava leaves: an excellent source of $\beta$-caryophyllene. Nat Prod Commun 14: 1 - 5. https://doi.org/10.1177/1934578x19843007

Bakkali F, Averbeck S, Averbeck D, Idaomar M. 2008. Biological effects of essential oil: a review. Food Chem Toxicol 46: 446 - 475. https://doi.org/10.1016/j.fct.2007.09.106

Baser, KHC, Buchbauer, G. 2010. Handbook of essential oils: science, technology and applications. CRC Press, Boca Raton/London/New York, USA.

Benitez NP, León EMM, Stashenko EE. 2009. Essential oil composition from two species of Piperaceae family grown in Colombia. J Chromatogr Sci 47: 804 - 807. https://doi.org/10.1093/chromsci/47.9.804

Booth C. 1971. Fungal culture media. In Norris JR, Ribbons DW: Methods in microbiology. Academic Press, London/New York, USA.

Burt, S. 2004. Essential oils: their antibacterial properties and potential applications in foods-a review. Int J Food Microbiol 94: 223 - 253. https://doi.org/10.1016/j.ijfoodmicro.2004.03.022

Castro MR, Victoria FN, Oliveira DH, Jacob RG, Savegnago L, Alves D. 2015. Essential oil of Psidium cattleianum leaves: antioxidant and antifungal activity. Pharm Biol 53: 242 - 250.

https://doi.org/10.3109/13880209.2014.914231

Boletín Latinoamericano y del Caribe de Plantas Medicinales y Aromáticas/624 
Chalannavar RK, Narayanaswamy VK, Baijnath H, Odhav B. 2012. Chemical composition of essential oil of Psidium cattleianum var. lucidum (Myrtaceae). Afric J Biotechnol 11: 8341 - 8347. https://doi.org/10.5897/ajb10.1942

Chalannavar RK, Narayanaswamy HB, Bharti OJ. 2013. Chemical constituents of the essential oil from leaves of Psidium cattleianum var. cattleianum. J Med Plants Res 7: 783 - 789.

Chen HC, Sheu MJ, Lin LY, Wu CM. 2007. Chemical composition of the leaf essential oil of Psidium guajava L. from Taiwan. J Essent Oil Res 19: 345 - 347. https://doi.org/10.1080/10412905.2007.9699300

CLSI. 2015. [Clinical and Laboratory Standards Institute]. Methods for dilution antimicrobial susceptibility tests for bacteria that grow aerobically; Approved Standard, CLSI document M07-A10. Wayne, USA.

De Lucas V, Salim V, Atsumi SM, Yu F. 2012. Mining the biodiversity of plants: a revolution in the making. Science 336: 1658 - 1661. https://doi.org/10.1126/science.1217410

Di Giacomo S, DI Sotto A, Mazzanti G, Wink M. 2017. Chemosensitizing properties of $\beta$-caryophyllene and $\beta$ caryophyllene oxide in combination with doxorubicin in human cancer cells. Anticancer Res 37: 1191 1196. https://doi.org/10.21873/anticanres.11433

Dias ALB, Batista HRF, Estevam EBB, Alves CCF, Forim MR, Nicolella HD, Furtado RA, Tavares DC, Silva TS, Martins CHG, Miranda MLD. 2018. Chemical composition and in vitro antibacterial and antiproliferative activities of the essential oil from the leaves of Psidium myrtoides O. Berg (Myrtaceae). Nat Prod Res 33: 2566 - 2570. https://doi.org/10.1080/14786419.2018.1457664

Dos Santos Pereira E, Vinholes J, Franzon CR, Dalmazo G, Vizzotto M, Nora L. 2018. Psidium cattleianum fruits: a review on its composition and bioactivity. Food Chem 258: 95 - 103. https://doi.org/10.1016/j.foodchem.2018.03.024

Espinel-Ingroff A. 2001. Comparison of the E-test with the NCCLS M38-P method for antifungal susceptibility testing of common and emerging pathogenic filamentous fungi. J Clin Microbiol 39: 1360 - 1367. https://doi.org/10.1128/jcm.39.4.1360-1367.2001

European Pharmacopoeia. 2013. VIII Ed. Council of Europe, Strasbourg, France.

Farhat GN, Affara NI, Gali-Muhtasib HU. 2001. Seasonal changes in the composition of the essential oil extract of East Mediterranean sage (Salvia libanotica) and its toxicity in mice. Toxicon 39: 1601 - 1605. https://doi.org/10.1016/s0041-0101(01)00143-x

FAO. 2017. [Food and Agriculture Organization]. The future of food and agriculture - Trends and challenges, Rome, Italy.

Garcia-Fuentes AR, Wirtz S, Vos E, Verhagen H. 2015. Short review of sulphites as food additives. Eur J Nutr Food Safety 5: 113 - 120. https://doi.org/10.9734/ejnfs/2015/11557

Guimarães DE, Momesso LS, Pupo MT. 2010. Antibiotics: therapeutic importance and perspectives for the discovery and development of new agents. Quim Nova 33: 667 - 679.

Gupta AK, Sauder DN, Shear NH. 1994. Antifungal agents: an overview. Part I. J Am Acad Dermatol 30: 677 698.

Hänel H, Raether W. 1988. A more sophisticated method of determining the fungicidal effect of water-insoluble preparations with a cell harvester, using miconazole as an example. Mycoses 31: 148 - 154. https://doi.org/10.1111/j.1439-0507.1988.tb03718.x

Hassler M. 2020. World plants: synonymic checklists of the vascular plants of the world (version Nov 2018). In: Species 2000 \& ITIS catalogue of life, 2019 Annual checklist (Roskov Y, Ower G, Orrell T, Nicolson D, Bailly N, Kirk PM, Bourgoin T, DeWalt RE, Decock W, Nieukerken E. van, Zarucchi J, Penev L, eds.). Digital resource at www.catalogueoflife.org/annual-checklist/2019 Species 2000: Naturalis, Leiden, the Netherlands.

Hendry ER, Worthington T, Conway BR, Lambert PA. 2009. Antimicrobial efficacy of eucalyptus oil and 1,8cineole alone and in combination with chlorhexidine digluconate against microorganisms grown in planktonic and biofilm cultures. J Antimicrob Chemother 64: 1219 - 1225.

https://doi.org/10.1093/jac/dkp362

Kovar KA, Gropper B, Friess D, Ammon HP. 1987. Blood levels of 1,8-cineole and locomotor activity of mice after inhalation and oral administration of rosemary oil. Planta Med 53: 315 - 318. https://doi.org/10.1055/s-2006-962725

Macêdo DG, Souza MMA, Morais-Braga MFB, Coutinho HDM, Dos Santos ATL, da Cruz RP, da Costa JGM, Coutinho HDM, Santos ATL, Machado AJT, Rodrigues FFG, da Costa JGM, de Menezes IRA. 2020. 
Seasonality influence on the chemical composition and antifungal activity of Psidium myrtoides O. Berg. South Afric J Bot 128: 9 - 17. https://doi.org/10.1016/j.sajb.2019.10.009

Manoel AN, José WA, Adriano NC, Edilberto RS, Terezinha GB. 1994. Volatile constituents of Psidium pohlianum and Psidium guyanensis Pers. J Essent Oil Res 6: 299 - 300.

Marques FA, Wendler EP, Maia BHLN, Coffani-Nunes JV, Campana J, Guerrero Jr PG. 2008. Volatile oil of Psidium cattleianum Sabine from the Brazilian Atlantic forest. J Essent Oil Res 20: 519 - 520. https://doi.org/10.1080/10412905.2008.9700077

Mccook-Russell PK, Nair MG, Facey PC, Bowen-Forbes CS. 2012. Nutritional and nutraceutical comparison of Jamaican Psidium cattleianum (strawberry guava) and Psidium guajava (common guava) fruits. Food Chem 134: 1069 - 1073. https://doi.org/10.1016/j.foodchem.2012.03.018

Medeiros FCM, Del Menezzi CHS, Bizzo HR, Vieira RF. 2015. Scents from Brazilian Cerrado: Psidium myrsinites DC. (Myrtaceae) leaves and inflorescences essential oil. J Essent Oil Res 27: 289 - 292. https://doi.org/10.1080/10412905.2015.1037020

Modolo LV, Foglio MA. 2019. Brazilian medicinal plants. 1st ed. CRC Press/Taylor \& Francis Group, Boca Raton, Florida, USA.

Morais LAS, Castanha RF. 2012. Chemical composition of sweet basil essential oil naturally submitted to Planococcus citri infestation. Hortic Bras 30 (2): S 2178-S 2182.

Neta MCS, Vittorazzi C, Guimarães AC, Martins D L, Fronza M, Coutinho D E, Scherer R. 2017. Effects of $\beta$ caryophyllene and Murraya paniculata essential oil in the murine hepatoma cells and in the bacteria and fungi 24-h time-kill curve studies. Pharm Biol 55: 190 - 197. https://doi.org/10.1080/13880209.2016.1254251

O’Neill J. 2016. Review on antimicrobial resistance: tackling drug-resistant infections globally: final report and recommendations. Wellcome Trust, London, England.

Oh MS, Yang JY, Kim MG, Lee HS. 2014. Acaricidal activities of $\beta$-caryophyllene oxide and structural analogues derived from Psidium cattleianum oil against house dust mites. Pest Manag Sci 70: 757 - 762. https://doi.org/10.1002/ps.3608

Pandey AK, Sonker N, Singh P. 2016. Efficacy of some essential oil against Aspergillus flavus with special reference to Lippia alba oil an inhibitor of fungal proliferation and aflatoxin B1 production in green gram seeds during storage. J Food Sci 81: 928 - 934. https://doi.org/10.1111/1750-3841.13254

Paramythiotou E, Routsi C. 2016. Association between infections caused by multidrug-resistant gram-negative bacteria and mortality in critically ill patients. World J Crit Care Med 5: 111 - 120.

https://doi.org/10.5492/wjccm.v5.i2.111

Pino JA, Bello A, Urquiola A. 2004. Leaf oils of Psidium parvifolium Griseb. and Psidium cattleianum Sabine from Cuba. J Essent Oil Res 16: 370 - 371. https://doi.org/10.1080/10412905.2004.9698745

PubChem. 2020a. Open Chemistry Database, National Institutes of Health. Gamma-muurolene, CID: 12313020. https://pubchem.ncbi.nlm.nih.gov/compound/gamma-Muurolene

PubChem. 2020b. Open Chemistry Database, National Institutes of Health. Santalol A, CID: 5368797. https://pubchem.ncbi.nlm.nih.gov/compound/Santalol-A

PubChem. 2020c. Open Chemistry Database, National Institutes of Health. (-)-delta-Selinene, CID: 12308845. https://pubchem.ncbi.nlm.nih.gov/compound/12308845

PubChem. 2020d. Open Chemistry Database, National Institutes of Health. (+)-delta-Cadinene, CID: 441005. https://pubchem.ncbi.nlm.nih.gov/compound/delta-Cadinene

PubChem. 2020e. Open Chemistry Database, National Institutes of Health. (-)-Globulol, CID: 12304985. https://pubchem.ncbi.nlm.nih.gov/compound/12304985

Rawat S. 2015. Food spoilage: microorganisms and their prevention. Asian J Plant Sci Res 5 (4): 47-56.

Rodenak-Kladniew B, Castro A, Stärkel P, Galle M, Crespo R. 2020. 1,8-cineole promotes G0/G1 cell cycle arrest and oxidative stress-induced senescence in HepG2 cells and sensitizes cells to anti-senescence drugs. Life Sci 243: 1 - 13. https://doi.org/10.1016/j.lfs.2020.117271

Salen N, Kefi S, Tabben O, Ayed A, Jallouli S, Feres N, Elkahoui S. 2018. Variation in chemical composition of Eucalyptus globulus essential oil under phenological stages and evidence synergism with antimicrobial standards. Ind Crops Prod 124: 115 - 125. https://doi.org/10.1016/j.indcrop.2018.07.051

Santos FA, Rao VS. 2000. Antiinflammatory and antinociceptive effects of 1,8-cineole a terpenoid oxide present in many plant essential oils. Phytother Res 14: 240 - 244.

Boletín Latinoamericano y del Caribe de Plantas Medicinales y Aromáticas/626 
https://doi.org/10.1002/1099-1573(200006)14:4<240::aid-ptr573>3.0.co;2-x

Scur MC, Pinto FGS, Pandini JA, Costa WF, Leite CW, Temponi LG. 2016. Antimicrobial and antioxidant activity of essential oil and different plant extracts of Psidium cattleianum Sabine. Braz J Biol 76: 101 - 108. https://doi.org/10.1590/1519-6984.13714

Silva EAJ, Estevam EBB, Silva TS, Nicolella HD, Furtado RA, Alves CCF, Souchie EL, Martins CHG, Tavares DC, Barbosa LCA, Miranda MLD. 2019. Antibacterial and antiproliferative activities of the fresh leaf essential oil of Psidium guajava L. (Myrtaceae). Braz J Biol 79: 697 - 702. https://doi.org/10.1590/1519-6984.189089

Sivakumar D, Bautista-Baños S. 2014. A review on the use of essential oils for postharvest decay control and maintenance of fruit quality during storage. Crop Prot 64: 27 - 37. https://doi.org/10.1016/j.cropro.2014.05.012

Soliman FM, Fathy MM, Salama MM, Saber FR. 2016. Comparative study of the volatile oil content and antimicrobial activity of Psidium guajava L. and Psidium cattleianum Sabine leaves. Bull Fac Pharm Cairo Univ 54: 219 - 225. https://doi.org/10.1016/j.bfopcu.2016.06.003

Stefanakis MK, Touloupakis E, Anastasopoulos E, Ghanotakis D, Katerinopoulos HE, Makridis P. 2013. Antibacterial activity of essential oils from plants of the genus Origanum. Food Control 34: 539 - 546. https://doi.org/10.1016/j.foodcont.2013.05.024

Sun Y, Cai X, Cao J, Wu Z, Pan D. 2018. Effects of 1,8-cineole on carbohydrate metabolism related cell structure changes of Salmonella. Front Microbiol 9: 1 - 11. https://doi.org/10.3389/fmicb.2018.01078

Tong SYC, Davis JS, Eichenberger E, Holland TL, Fowler VG. 2015. Staphylococcus aureus infections: epidemiology, pathophysiology, clinical manifestations, and management. Clin Microbiol Rev 28: 603 661. https://doi.org/10.1128/cmr.00134-14

Vilela GR, Almeida GS, D'Arce MABR, Moraes MHD, Brito JO, da Silva MFGF, Silva SC, de Stefano Piedade SM. 2009. Activity of essential oil and its major compound, 1,8-cineole, from Eucalyptus globulus Labill., against the storage fungi Aspergillus flavus Link and Aspergillus parasiticus Speare. J Stored Prod 45: 108 - 111. https://doi.org/10.1016/j.jspr.2008.10.006

Vuuren SF, Viljoen AM. 2007. Antimicrobial activity of limonene enantiomers and 1,8-cineole alone and in combination. Flavour Fragr J 22: 540 - 544. https://doi.org/10.1002/ffj.1843

WHO - World Health Organization. 2015. WHO estimates of the global burden of foodborne diseases: foodborne disease burden epidemiology reference group 2007-2015. https://apps.who.int/iris/bitstream/handle/10665/199350/9789241565165_eng.pdf?sequence=1

Widianingrum DC, Noviandi CT, Salasia SI. 2019. Antibacterial and immunomodulator activities of virgin coconut oil (VCO) against Staphylococcus aureus. Heliyon 5: E02612.

https://doi.org/10.1016/j.heliyon.2019.e02612

Younis NS, Mohamed ME. 2019. $\beta$-caryophyllene as a potential protective agent against myocardial injury: the role of toll-like receptors. Molecules 24: 1 - 16. https://doi.org/10.3390/molecules24101929

Zhu L, He J, Cao X, Huang K, Luo Y, Xu W. 2016. Development of a double-antibody sandwich ELISA for rapid detection of Bacillus cereus in food. Sci Rep 15: 1 - 10. https://doi.org/10.1038/srep16092 